\title{
Familial atrial septal defect in the oval fossa with progressive prolongation of the atrioventricular conduction caused by mutations in the NKX2.5 gene - ERRATUM
}

Per G. Bjørnstad, Trond P. Leren

doi:10.1017/S1047951108003387, Published by Cambridge University Press 2 December 2008.

Due to a publisher error, the wrong Figure 1 was included within the above paper (Bjørnstad PG, Leren TP, 2009). Please find the correct Figure 1 below. The publishers apologise for this error.

\section{Reference}

Bjørnstad PG, Leren TP. Familial atrial septal defect in the oval fossa with progressive prolongation of the atrioventricular conduction caused by mutations in the NKX2.5 gene. Cardiol Young 2009; 19: 40-44.

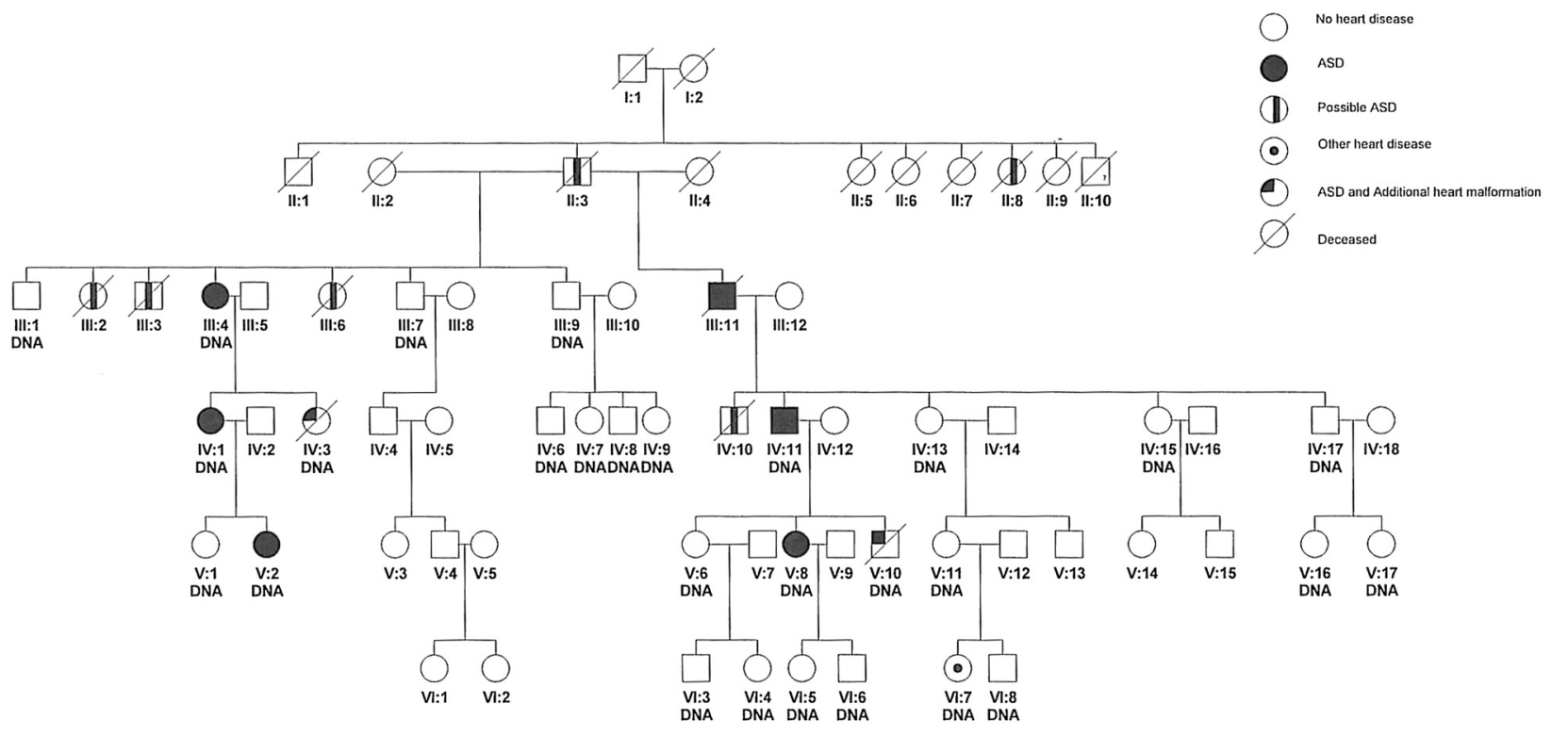

Figure 1. 